\title{
International Holding Company as an Optimal Structure for Optimizing Tax Liabilities of Taxpayers
}

\author{
Garaeva E. K. ${ }^{1}$ \\ ${ }^{1}$ Kazan Federal University, Institute of Management, Economics and Finance, Kazan, Russia \\ Correspondence: Garaeva E. K., Kazan Federal University, Institute of Management, Economics and Finance, \\ Kazan, 420008, Russia.
}

Received: March 10, 2015 Accepted: March 31, 2015 Online Published: April 30, 2015

doi:10.5539/ass.v11n11p137 URL: http://dx.doi.org/10.5539/ass.v11n11p137

\begin{abstract}
The paper analyzes the tax issues of holding companies using the example of the EU countries. The article describes and studies a number of ways to optimize the taxation of international holding companies; discusses the challenges currently faced by the tax authorities of different countries in the implementation of tax control over the functioning of the integrated structures. The paper considers advantages and disadvantages of tax optimization of international holding companies, the cost of coming to and going out of the market of a country and doing business there. The author determines the basic functions and purposes of establishing a holding company structure, in the case of its use for tax optimization at all group companies; identifies new opportunities to optimize the taxation of their income in the context of globalization.
\end{abstract}

Keywords: optimization of taxation, tax planning, globalization, integrated holding structures, international holding company, minimization of tax burden

\section{Introduction}

Globalized economic environment, intensive development of global economic and interbank relations, having determined the removal of restrictions on the free movement of capital, increasing competition in the global and domestic financial markets determine the establishment of integrated holding structures (IHS) all over the world under the influence of integrating processes common for all countries. HIS are established with particular purposes in mind (Baldwin \& Okubo, 2009). They usually include winning new market sectors and / or cost reduction. Both of these factors increase the cost of the company, its capitalization (Becker \& Fuest, 2011). Achieving this goal requires effective work on the business organization, reduction of transaction costs and the related tax treatment provided by the country where production would be located. In this case comparative analysis of countries tax cost becomes an important element of a company's research policy, designed to minimize costs and maximize profits when placing its production units (Hadden, 2012). The process of globalization and the general trend of companies to operate within common European economic environment provide new opportunities for taxpayers to optimize the taxation of their profit. An increasing tax burden also serves as a prerequisite for taxpayers aspirations to tax optimization.

Development of new industries in the service sector, as well as the increased mobility of companies operating in these sectors (in particular, this applies to online business and e-commerce) has led to additional difficulties in taxation (Chiang, 2003). The main problem faced currently by the tax authorities of different countries, is the need to ensure effective fiscal control over the functioning of the integrated structures in circumstances where it is sometimes almost impossible to determine which country the object of taxation originates from (Boadway et al., 2002). Currently this tax problem is considered in the framework of the WTO, the OECD, the EU and other intergovernmental organizations, which once again proves the need for a broad international coordination on matters relating to cross-country aspects of taxation (Gajewski, 2013).

Russia's transition to sustainable economic growth in modern conditions is closely linked with new opportunities to optimize the taxation of income of the integrated structures. The need for tax planning is driven by the realities of business and the need to operate with ever increasing requirements of the tax legislation, particularly regulating international activities, as well as the desire to reduce their costs, including taxes, in terms of increasing tax burden (Slemrod, 2012). 


\section{Theory}

There are different types of integrated structures, which may be represented by international corporations, multinational companies, groups of corporations and other organizations.

Meanwhile, the up-to-date grouping of a holding type requires one integrated theoretical framework that allows to answer a number of important questions: organization of what kind, size, and management system will give the desired effect and will contribute to the development of the economic system of society (Osmunden, et.al., 1998). The Theory of Constraints states that there are only three financial indicators one should be focused on:

1. The rate of generating income;

2. The associated capital;

3. The operating expenses.

The goal of any company in these terms is as follows: to increase the rate of generating income while reducing the associated capital and operating expenses (Whittred, 1987).

In accordance with the tax laws of most European countries, as well as the Russian legislation, the main subject of taxation is a legal entity. Taxation of holding companies in the world involves the taxation of separate legal entities that are the part of the holding company or taxation of a holding company as a single taxpayer. For tax purposes, the type of holding organization is not important, since taxation is made at the level of the company - a legal entity.

Operating internationally one of the options to optimize taxation is to establish an international holding company, in which each unit has a clear role that allows to optimize the use of domestic financial and economic resources, distribute profits and use it for the development of the Group's businesses in the future while achieving optimal taxation at the level of the holding company as a whole (Bayindir \& Ziad, 2005).

Using international statistics as a basis, we can conclude that the degree of influence of taxation factor on economic growth in developed countries is quite large and has a tendency to increase. Analyzing the tax issues of holding companies by the example of five countries (Austria, Denmark, Spain, Germany, Czech Republic) as the most frequently used areas to accommodate the holding companies in the implementation of international tax planning, it can be noted that in spite of a slight decrease in the tax burden for EU countries in the period of 2000-2005 from $39.4 \%$ to $38.4 \%$ in 2005 , the tax burden began to increase in 2007 again and amounted to $41.5 \%$ of GDP in 2013 (OECD. Stat Extracts).

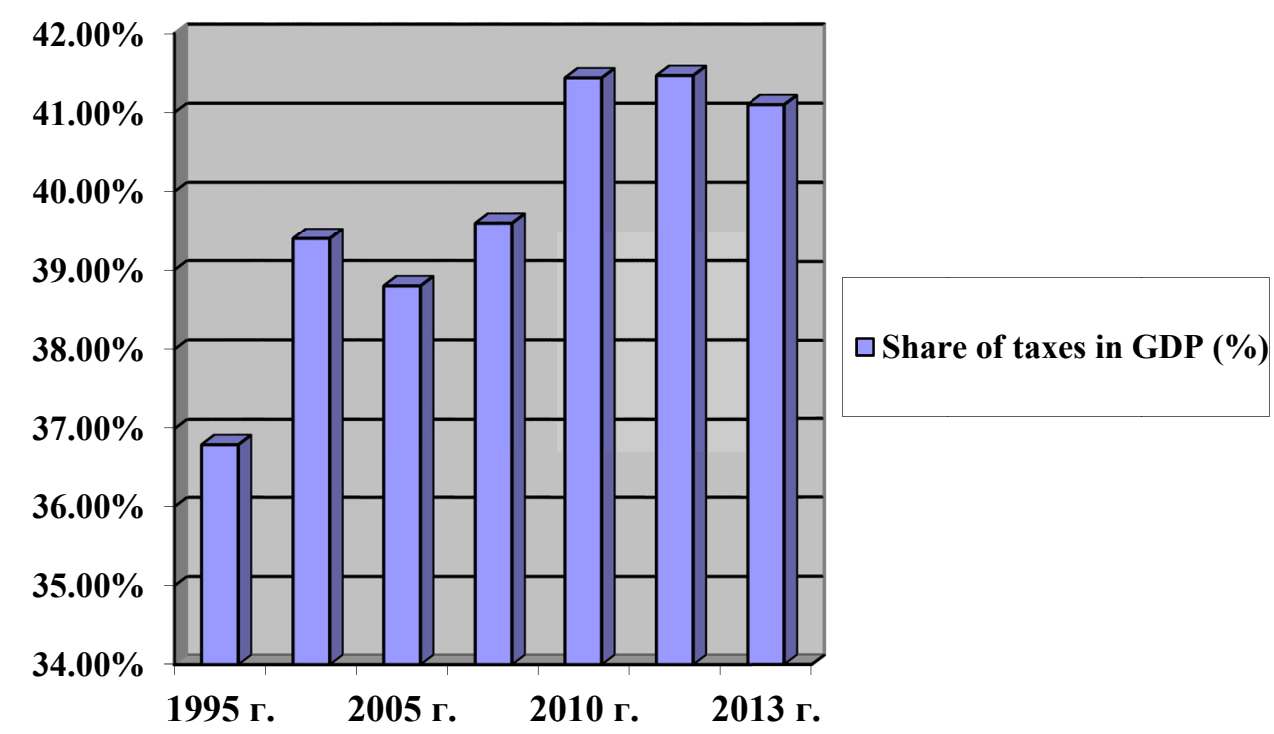

Figure1. Dynamics of tax revenues to the EU countries on average in \% of GDP 
An interesting fact is that the tax burden as a percentage of GDP in the countries is growing, despite the reduction in tax rates for many significant taxes such as income tax (Figure 2), reflecting the strong economic growth of national economies, leading, in turn, to an increase in corporate profits (European Commission Official Site).

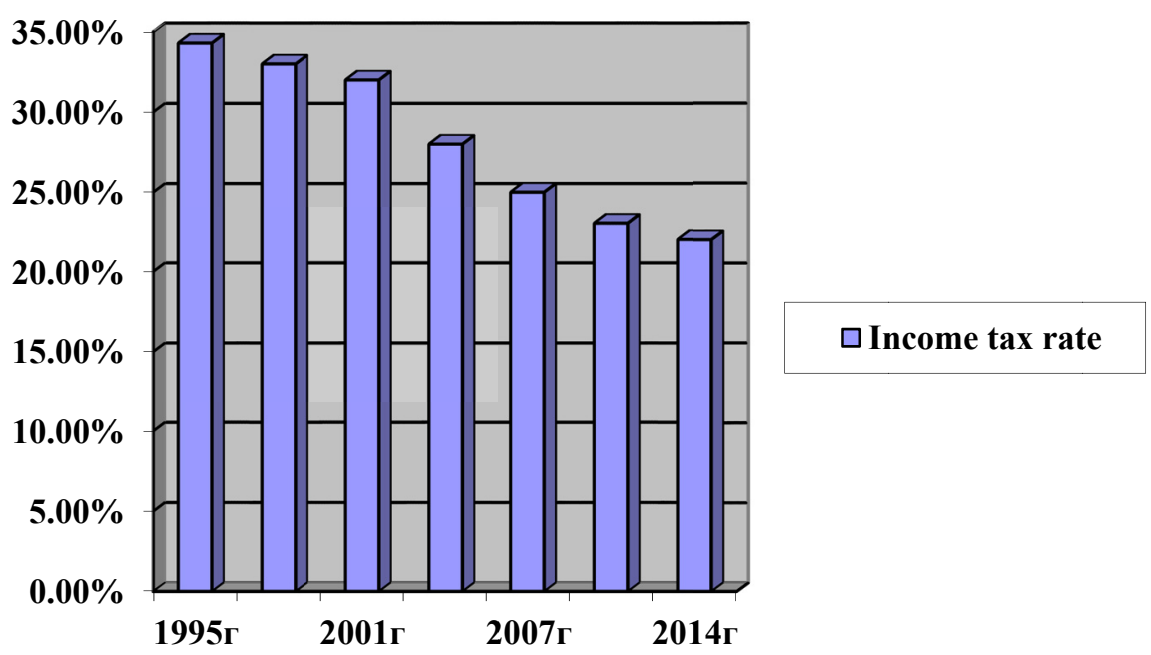

Figure 2. Change in income tax rate in the EU countries on average in 1995-2014

According to the latest data, the share of tax revenues as a percentage of GDP in the analyzed countries has increased (see Table 1) (European Commission. Taxation and Customs Union).

Table 1. Tax revenue in the EU (\% of GDP)

\begin{tabular}{ccccccc}
\hline & 2000 & 2005 & 2010 & 2011 & 2012 & 2013 \\
\hline Austria & 1,85 & 2,07 & 1,75 & 1,86 & 1,74 & 1,92 \\
Denmark & 2,79 & 2,93 & 1,88 & 1,72 & 1,90 & 1,94 \\
Spain & 3,14 & 3,93 & 1,89 & 1,82 & 2,16 & 2,21 \\
Germany & 1,20 & 0,80 & 0,52 & 0,64 & 0,66 & 0,69 \\
Czech Republic & 3,36 & 4,33 & 3,36 & 3,38 & 3,32 & 3,35 \\
\hline
\end{tabular}

Due to the complexity the tax legislation of the EU, rather stringent requirements for taxpayers and increase of the tax burden taxpayers are forced to employ various ways to minimize their tax liabilities, which are often viewed as risky operations.

In the process of globalization states offer their tax regimes in the international market. The main tax problems faced by all countries, including the European are as follows: the complexity of the tax system for taxpayers understanding, that generates all sorts of tax evasion; the inequity of tax burden when the same income may be taxed differently; high tax rates; companies making investment not for economic but for tax reasons; the trend of national tax systems for direct taxes. As a consequence, one can observe the tightening of the state's position in relation to schemes used by taxpayers and changes in the state climate for tax planning from favorable to aggressive.

When establishing the optimal structure of the holding company it is very important to build the right relationships between different parts of the holding company and the distribution of functions between group companies. For example, in international activities, location of various departments depending on the type of activity and the nature taxation of the proposed operations plays a great role. 
It is important to note the following main functions and objectives of establishing a holding company structure, in the case of its use for tax optimization at all group companies:

-Consolidation of companies' assets, institutionalizing of companies groups (the transparency and clarity of structure for potential lenders and investors), flexible, mobile structures, the ability to adapt to changing conditions;

-Creation of the investment attractiveness of the companies groups, raising financial resources and further financing of group companies;

-Use of a foreign holding company as the parent company to create subsidiaries, intended for "one-off" operations in different countries or for resale to potential investors;

-Offering additional opportunities for development and expansion of the scope of the group companies, the optimization of cash flows within the group, as well as the accumulation of financial resources in the units where they are most needed at this time, the expansion of foreign and national clientele;

Getting a loan by subsidiaries in bank branches of the company's country secured by a deposit placed by a holding company with a foreign bank and minimizing the tax consequences of making loans.

It should be noted that the choice of jurisdiction for the incorporation of the management company is carried out on the basis of financial and non-financial factors. Financial factors are mainly determined by the level of taxation of holding companies in a particular country. To estimate the tax burden in the world community one can use the tax burden, which is the sum of the current maximum interest rates for all taxes (regardless of the tax base). This indicator reflects the level of tax rates in the country and it can be used to carry out a comparison of the tax burden among countries. Accordingly, the lower is this indicator, the less is the tax burden and vice versa.

However, in determining the taxation of international integrated structures one should not rely solely on tax rates. The actual tax paid can be significantly lower than that calculated at the fixed rate due to the use of a number of additional tax benefits, as well as the availability of special tax regimes for holding companies. That is, the tax rates are not significant in terms of economic activity taxation. This is confirmed by the fact that in conditions of full freedom of capital movements, the companies continue to operate in European countries with the level of corporation tax of $30-40 \%$ and do not move to "tax havens", where the tax rate up $2.5 \%$, or is not charged at all.

The main strategic objective of the EU is striving to become more globally competitive, dynamic and socially oriented economy showing steady economic growth. It should be noted that from a tax point of view, many EU countries have established themselves as the preferred locations for the establishment of the managing company. EU countries have the best reputation, as they are developed, are the member states of the internationally recognized economic and economic - political associations (e.g., are the part of the EU and the OECD). This membership offers advantages in relations with other states of the association and ensures the stability of the political and economic situation in the country.

\section{Conclusion}

Knowledge of specific methods of tax optimization, their advantages and disadvantages, costs of coming into and going out of the country's market and doing business in it become one of the important factors in the decision to use a particular method of tax optimization in practice. Priority of cross-country relations in the field of taxation is the formation of a common information space and mutual cooperation, as well as timely notification of new emerging mechanisms of tax optimization. The states set as their objectives achieving accessibility, transparency and openness of the tax authorities for taxpayers, that is, is an attempt to change the position of the tax authorities in respect of a taxpayer from a hostile party to friendly.

With regard to the measures taken by the Russian government and planned innovations regarding the taxation of Russian holding companies, they are of fundamental importance, since in 2014 there is no single legislative act for holding companies or other associations of legal entities in Russia. Thus, the planned transformation of the holding in a single taxpayer, through, for example, exemption from the profit transfer tax within the holding companies, from tax on dividends, or by calculating the tax liability from the consolidated income. It is also planned to introduce a number of state tax policy measures aimed at the use of offshore areas in tax planning (Hong \& Smart, 2010). Estimated innovations include consideration of "controlled foreign companies" income (subsidiary of a Russian legal entity registered in the offshore) as a profit of a Russian parent companies and, accordingly, to impose tax in Russia on the grounds that it is controlled and operating in Russia. And the main task of the state, both in Russia and in the EU is to tighten control over the activities of companies in the offshore areas, the introduction of an information exchange with such areas, and making appropriate changes to the legislation. In order to address these challenges effectively, it is necessary to establish a more favorable tax 
climate in Russia, assistance to taxpayers by the tax authorities and the elimination of a number of bureaucratic requirements.

\section{References}

Adigamova, F. F., Safiullin, M. A., \& Tufetulov, A. M. (2014). Mechanism of state tax regulation in the global economy. Mediterranean Journal of Social Sciences, 5(24), 193-199. http://dx.doi.org/10.5901/mjss.2014. v5n24p193

Ajupov, A. A., Artamonov, A. B., Kurilov, K. U., \& Kurilova, A. A. (2014). Economic bases of formation and development of financial engineering in financial innovation. Mediterranean Journal of Social Sciences, 5(24), 148-153. http://dx.doi.org/10.5901/mjss.2014.v5n24p148

Ajupov, A. A., Mishina, M. S., \& Ivanov, M. E. (2014). Method of valuation of financial factors influencing the implementation of liquidity risk for leasing companies. Mediterranean Journal of Social Sciences, 5(24), 154-159. http://dx.doi.org/10.5901/mjss.2014.v5n24p154

Baldwin, R., \& Okubo T. (2009). Tax reform, delocation, and heterogeneous firms. Scandinavian Journal of Economics, 111(4), 741-764. http://dx.doi.org/10.1111/j.1467-9442.2009.01582.x

Bayindir-Upmann, T., \& Ziad, A. (2005). Existence of equilibria in a basic tax-competition model. Regional Science and Urban Economics, 35(1), 1-22. http://dx.doi.org/10.1016/j.regsciurbeco.2003.01.001

Becker, J., \& Fuest, C. (2011). Optimal tax policy when firms are internationally mobile. International Tax and Public Finance, 18(5), 580-604. http://dx.doi.org/10.1007/s10797-011-9168-x

Boadway, R., Cuff, K., \& Marceau, N. (2002). Inter-Jurisdictional competition for firms. International Economic Review, 43(3), 761-782. http://dx.doi.org/10.1111/1468-2354.t01-1-00034

Chiang T.-J. (2003). State Income Taxation of Out-of-State Trademark Holding Companies. University of Chicago Law Review, 70(4), 1533-1553. http://dx.doi.org/10.2307/1600580

European Commission Official Site. Retrieved from http://ec.europa.eu/atoz_en.htm

European Commission. Taxation and Customs Union. Retrieved from http://ec.europa.eu/taxation_customs/ common/about/welcome/index_en.htm

Gajewski, D. (2013). The holding company as an instrument of companies' tax-financial policy formation. Contemporary Economics, 7(1), 75-82. http://dx.doi.org/10.5709/ce.1897-9254.75

Hadden, T. (2012). Accountable Governance in Corporate Groups: The Interrelationship of Law and Accounting. Australian Accounting Review, 22(2), 117-128. http://dx.doi.org/10.1111/j.1835-2561.2012.00167.x

Hong, Q., \& Smart, M. (2010). In praise of tax havens: International tax planning and foreign direct investment. European Economic Review, 54(1), 82-95. http://dx.doi.org/10.1016/j.euroecorev.2009.06.006

Ibragimov, M., \& Tufetulov, A. M. (2014). Income distribution and market demand: the case of heterogeneous preferences. Mediterranean Journal of Social Sciences, 5(24), 185-187. http://dx.doi.org/10.5901/mjss.2014. v5n24p 185

OECD. Stat Extracts. Retrieved from http://stats.oecd.org/index.aspx? usercontext

Osmundsen, P., Hagen, K. P., \& Schjelderup, G. (1998). Internationally mobile firms and tax policy. Journal of International Economics, 45(1), 97-113. http://dx.doi.org/10.1016/S0022-1996(97)00028-7

Slemrod, J. (2010). Location, (REAL) location, (TAX) location: An essay on mobility's place in optimal taxation. National Tax Journal, 63(4), 843-864.

Whittred, G. (1987). The derived demand for consolidated financial reporting. Journal of Accounting and Economics, 9(3), 259-285. http://dx.doi.org/10.1016/0165-4101(87)90008-5

\section{Copyrights}

Copyright for this article is retained by the author(s), with first publication rights granted to the journal.

This is an open-access article distributed under the terms and conditions of the Creative Commons Attribution license (http://creativecommons.org/licenses/by/3.0/). 